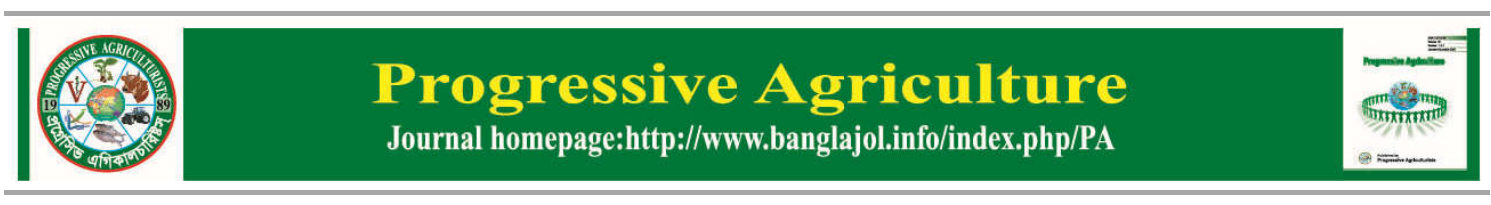

\title{
Investigation on quality and management of wheat seed in Bogra and Naogaon
}

\author{
F Naznine, I Hossain ", MA Akter \\ Department of Plant Pathology, Bangladesh Agricultural University, Mymensingh-2202, Bangladesh
}

\begin{abstract}
The quality of wheat seed samples of 11 varieties viz. Akbar, Kanchan, Barkat, Sonalika, Paban, Prodip, Satapdi, BARI gom 25, BARI gom 26, BARI gom 27 and BARI gom 28 from 7 different Upazillas of Bogra and 5 different Upazillas of Naogaon were tested and categorized into six components viz. Grade-0 (72 to $86.7 \%$ ), Grade-1 (2.9 to 7.5\%), Grade-2 (2.1 to 6.0\%), Grade-3 (1.7 to 4.5\%), Grade-4 (2.4 to 8.4\%) and Grade$5(1.5$ to $7.6 \%)$. The highest percentage of Grade-0 seeds $(86.7 \%)$ was recorded in wheat variety of BARI gom 28 and the lowest percentage of Grade- 0 seeds (72\%) was recorded in variety Kanchan. The moisture content of the seed samples ranged from 10.22 to $13.81 \%$, where the highest percentage of moisture content was found in wheat variety of Kanchan and the lowest in wheat variety of BARI gom 28. The 1000-seed weight ranged from 40.00 to $42.85 \mathrm{~g}$ where significantly highest weight was recorded in wheat variety of Sonalika followed by BARI gom 27 and the lowest in BARI gom 28. Health test by Blotter method resulted eight different seed borne fungi belonging to six genera viz. Bipolaris sorokiniana (0.5 to 30.5\%), Alternaria tenuis (0.5 to $25 \%$ ), Fusarium moniliforme (0.0 to 33.5\%), Fusarium oxysporum (2.7 to 53\%), Curvularia lunata (0.0 to 5.5\%), Aspergillus niger (0.0 to $18.5 \%$ ) and Penicillium spp. (0.0 to 1.5\%). Out of 11 samples tested germination of seeds ranged from 98.0 to $73.5 \%$. Wheat seeds of variety Kanchan was treated with plant extracts, BAUBiofungicide and chemical fungicides (Bavistin, Tilt and Provex) while the highest (11\%) incidence of Bipolaris sorokiniana was recorded in untreated control and the lowest $(0.0 \%)$ in seed treatment with BAUBiofungicide followed by seed treatment with Provax and Tilt. Seed germination ranged from 56.0 to $98.0 \%$ where the highest $(98.0 \%)$ and lowest $(56.0 \%)$ germination was recorded in case of seed treatment with BAUBiofungicide and Tilt. BAU-Biofungicide increased $41.75 \%$ vigor index over untreated control.
\end{abstract}

Key words: Wheat, seed treatment, quality, vigor index, management

Progressive Agriculturists. All rights reserve

*Corresponding Author: dhossain69@gmail.com

\section{Introduction}

Wheat (Triticum aestivum L.) is third most produced valuable cereal that has more protein than different nourishments. In 2015 about 721.55 million tons was produced and represented a decrease of 4.77 million tons or a $0.66 \%$ in production around the globe (USDA, 2015). A seed-borne pathogen present externally or internally or associated with the seed as contaminant, may cause seed abortion, seed rot, seed necrosis, reduction or elimination of germination capacity as well as seedling damage resulting in development of diseases at later stages of plant growth by systemic or local infection (Khanzada et al., 2002). Black point caused by Bipolaris sorokiniana is an important seed-borne disease of wheat in Bangladesh (Fakir et al., 1987; Fakir et al., (1989). It impaired seed germination and significant reduction in seedling vigour and grain yield (Hossain and Hossain, 2001 and Malaker and Mian, 2002). It is important that clean and healthy seeds are to be used as planting materials in order to increase 
germination and productivity. It is noticeable that proper disease control measures can sustainably improve the quality of wheat seeds and significantly increase the yield. The disease can be controlled by the application of fungicides but practice of chemical control is too costly, particularly for poor farmers in the country. Many researchers have tried to find safe and economical methods to control plant diseases by using extracts of different plant parts (Bdliya and Alkali, 2008 and Cohen et al., 2006). Plant extracts have antifungal effect and can be used as fungicidal seed treatments for the control of seed-borne fungi of wheat and for increasing seed germination (Sobiya $e t$ al., 2005). Biological control has been proposed as a replacement for chemical control of plant diseases (Harman, 2000). BAU-Biofungicide, a biological agent resulted significant higher germination and plant stand, less disease incidence and higher yield of different crops (Hossain, 2011, Hossain and Hossain, 2012). Keeping in consideration present work has been undertaken to determine the quality of wheat seeds collected from different upazillas of Bogra and Naogaon districts as well as to evaluate efficiency of selected plant extracts, BAU-Biofungicide and chemical fungicides to control seed borne fungi associated with wheat seeds.

\section{Materials and Methods}

The experiment was carried out in the Seed Pathology Centre (SPC) and Eco-friendly Plant Disease Management Laboratory, Department of Plant Pathology, BAU, Mymensingh during the period from March, 2014 to April, 2015.

Seed samples were collected from the farmers. The collected seed samples were brought directly to the Department of Plant Pathology, BAU, Mymensingh and stored in Eco-friendly Plant Disease Management Lab. Department of Plant Pathology, BAU, Mymensingh.

\section{Dry inspection, determination of moisture content and determination of 1000-seed weight of seed}

For dry inspection 1000-seeds per sample were visually inspected and graded into six categories. The grading was done following the 0-5 rating scale of CIMMYT (Gilchist, 1985). Moisture content of seed samples was determined with the help of electronic moisture meter before preserving seed. 1000-seed weight was taken with the help of electronic balance.

\section{Seed health test (Blotter method)}

To detect the seed borne pathogens associated with the seeds in seed samples the Blotter method was used by following International Rules for Seed Testing (ISTA, 1996).

\section{Management of seed borne fungi}

Treatments for controlling seed borne fungi were $T_{0}$ $=$ Untreated Control, $\mathrm{T}_{1}=$ Mehedi leaf extract (1:10), $\mathrm{T}_{2}=$ Basok leaf extract (1:10), $\mathrm{T}_{3}=$ Chirota plant extract $(1: 10), \mathrm{T}_{4}=$ Merigold leaf extract (1:10), $\mathrm{T}_{5}=$ BAU Bio-fungicide $(3 \%) \mathrm{T}_{6}=$ Provax $(0.4 \%), \mathrm{T}_{7}=$ Tilt $(0.3 \%)$ and $\mathrm{T}_{8}=$ Bavistin $(0.3 \%)$. Bavistin, Tilt@0.3\% and Provax@0.4\% solutions were used for seed treatment. The seeds were soaked in fungicidal solutions for 15 minutes. Then the fungicidal solutions were drained out and the treated seeds were allowed to be dried up on filter paper for some time. Then the seeds were ready for sown. In case of plant parts were chopped after cleaning in running tap water. The extracts were prepared by crushing the plant parts in a blender with distilled water in 1:1 ratio (eg. $1: 1=100 \mathrm{~g}$ plant material crushed in $100 \mathrm{ml}$ water) following the method of Hossain et al., 1997. The extracts were 1:10 dilution ratio for seed treatment.

\section{Seed treatment with BAU Bio-fungicide}

BAU-Biofungicide (3g) mixed with $100 \mathrm{ml}$ water in a flask and seeds were treated. The treated seeds were then kept for 15 minutes and then subjected to the moist blotters in petridishes. The treated seeds were allowed to be dried up on filter paper for some time. Then the seeds were ready for sowing.

\section{Germination and Vigor test (Tray method)}

This study was carried out in the Net house of Seed Pathology Centre, BAU, Mymensingh using sand culture in tray method. Seeds were sown after treating as per treatment including a untreated control on sand in each plastic tray (18" x 9") in five lines (20 seeds/line) as per each treatment. A total of 200seeds were set for each treatment according to ISTA rules (ISTA, 1996) for testing germination of seeds. Germination was recorded at 14 days after sowing 
and tested according to ISTA rules for testing vigour of seedlings (ISTA, 2001). After 14 days shoot and root length were measured by using measuring scale. 20 seedlings per treatment from each tray were randomly selected for measurement of shoot or root length.

The seedling vigor was determined following the formula of Baki and Anderson, 1972. The collected data were analyzed by using Duncan's Multiple Range Test (DMRT) at 5\% level of probability following the MSTAT-C program following the procedure as described by Gomez and Gomez (1984).

\section{Results and Discussions}

\section{Determination of Dry inspection, moisture content and 1000-seed weight of wheat seeds}

Findings on dry inspection, moisture content and 1000 -seed weight of 11 wheat varieties are presented in Table 1. The wheat seeds were categorized into 6 grades viz. Grade-0 (72 to $86.7 \%$ ), Grade-1 (2.9 to $7.5 \%)$, Grade-2 (2.1 to $6.0 \%)$, Grade-3 (1.7 to $4.5 \%$ ), Grade-4 (2.4 to 8.4\%) and Grade-5 (1.5 to $7.6 \%)$.The highest number of apparently healthy seed (86.7\%) was recorded from wheat variety of BARI gom 28 collected from Rampur under Manda upazilla of Naogan District. Out of the materials tested, seeds samples contained 72 to $86.7 \%$ apparently healthy seeds (Grade-0). Only four varieties viz. BARI gom 28, BARI gom 25, Sonalika, Akbar and Paban showed apparently healthy seeds (Grade-0) ranged from 85 to $86.7 \%$. These four varieties can be considered good quality varieties, while the others were found to be variety of poor quality. This present finding was supported by Hossain (2012) who recorded $74-82.4 \%$ apparently healthy seeds in variety Kanchan when plots were not sprayed in case of field study. The moisture content of the seed sample ranged from 10.22 to $13.81 \%$, where the highest percentage of moisture content was found in wheat variety of Kanchan collected from Dupchachanchia of Bogra and the lowest in wheat variety of BARI gom 28 collected from Rampur under Manda upazilla of Naogan, respectively. Out of samples tested, Kanchan having high moisture content. High moisture initiated incomplete physiological process of germination resulting in loss of viability (Harrington, 1972). The 1000-seed weight was found to vary significantly from one variety to another as well as one location to another and ranged from 40.00 to $42.85 \mathrm{~g}$ where significantly highest weight was recorded in wheat variety of Sonalika collected from Sonatola of Bogra district followed by BARI gom 27 of Durgapur under Manda upazilla of Naogan and the lowest in BARI gom 28 collected from Rampur under Manda upazilla of Naogan. But 8 samples of wheat variety Sonalika collected from other different 8 location and weight ranged (40.20 to $42.85 \mathrm{~g}$ ) differ from one to another because of seed size. This result supported by (Alberta Agriculture and Food: Agdex, 2007) which reported 1000-seed weight is a measure of seed size. Seed size and the 1000-seeds weight can vary from one crop to another between varieties of the same crop and even from year to year or from field to field of same variety.

\section{Germination and incidence of seed borne fungi (Blotter method)}

Altogether eight different seed borne fungi belonging to six genera viz. Bipolaris sorokiniana (0.5 to $30.5 \%$ ), Alternaria tenuis (0.5 to 25\%), Fusarium moniliforme (0.0 to $33.5 \%$ ), Fusarium oxysporum (2.7 to 53\%), Curvularia lunata (0.0 to 5.5\%), Aspergillus niger (0.0 to $18.5 \%$ ) and Penicillium spp. ( 0.0 to $1.5 \%)$. Out of the samples tested germination of seeds ranged from 98.0 to $73.5 \%$ (Blotter method). The highest incidence of Bipolaris sorokiniana was recorded in Kanchan collected from Dupchanchia of Bogra district is presented in Table 2. This present finding is supported by the result of Hossain and Hossain (2001) who reported incidence of Bipolaris sorokiniana and Fusarium increased the infection black point but incidence of Alternaria tenuis and Curvularia lunata did not show any speci c relation with severity of black point infection in grain. Percent of germination ranged from $73.5 \%$ to $98.0 \%$ (Blotter method) that varied from variety to variety as well as one location to another (Table 2). The highest germination was recorded in seed sample of wheat variety of BARI gom 28 collected from Rampur under Manda upazilla of Naogan and the lowest in wheat variety of Kanchan collected from 
Table 1. Dry inspection, moisture content and 1000-seed weight of wheat seed sample collected from different Upazillas of Bogra and Naogaon

\begin{tabular}{|c|c|c|c|c|c|c|c|c|c|c|}
\hline \multirow{2}{*}{$\begin{array}{l}\text { SI. } \\
\text { No. }\end{array}$} & \multirow[t]{2}{*}{ Variety } & \multirow[t]{2}{*}{ Location of seed collection } & \multicolumn{6}{|c|}{ Different grading of seeds (\%) } & \multirow{2}{*}{$\begin{array}{c}\% \\
\text { Moisture } \\
\text { Content }\end{array}$} & \multirow{2}{*}{$\begin{array}{l}\text { 1000-seed } \\
\text { weight } \\
\text { (g) }\end{array}$} \\
\hline & & & 0 & 1 & 2 & 3 & 4 & 5 & & \\
\hline 1 & Akbar & Dupchanchia of Bogra & 85.0 & 3.2 & 2.5 & 3.3 & 3.0 & 3.0 & $12.29 \mathrm{~d}$ & $40.20^{\mathrm{gh}}$ \\
\hline 2 & Kanchan & Dupchanchia of Bogra & 72.0 & 3.5 & 4.0 & 2.5 & 8.4 & 7.6 & $13.81 \mathrm{a}$ & $41.70^{\text {cd }}$ \\
\hline 3 & Barkat & Kahaloo of Bogra & 82.0 & 3.0 & 5.5 & 4.1 & 2.8 & 2.6 & $11.84 \mathrm{e}$ & $40.80^{\mathrm{f}}$ \\
\hline 4 & Sonalika & Kahaloo of Bogra & 85.0 & 3.1 & 3.4 & 3.0 & 3.0 & 2.5 & $11.83 \mathrm{ef}$ & $42.30^{\mathrm{b}}$ \\
\hline 5 & Paban & Alta, Nandigram of Bogra & 80.0 & 5.0 & 5.5 & 3.5 & 4.0 & 2.0 & $11.71 \mathrm{i}$ & $40.25^{\text {gh }}$ \\
\hline 6 & sonalika & Alta, Nandigram of Bogra & 85.0 & 4.0 & 3.5 & 2.2 & 3.0 & 2.3 & $11.82 \mathrm{f}$ & $41.20^{\mathrm{e}}$ \\
\hline 7 & Paban & Bijrul, Nandigram of Bogra & 85.0 & 3.5 & 3.0 & 3.0 & 2.5 & 3.0 & $11.73 \mathrm{~h}$ & $40.50^{\mathrm{fg}}$ \\
\hline 8 & Sonalika & Bijrul, Nandigram of Bogra & 79.0 & 7.5 & 4.5 & 3.0 & 3.4 & 2.6 & 10.911 & $41.70^{\text {cd }}$ \\
\hline 9 & Prodip & Sonatola of Bogra & 81.0 & 3.5 & 5.0 & 3.0 & 4.5 & 3.0 & $11.82 \mathrm{f}$ & $41.80^{\mathrm{c}}$ \\
\hline 10 & Sonalika & Sonatola of Bogra & 86.0 & 6.3 & 2.1 & 1.7 & 2.4 & 1.5 & $12.30 \mathrm{~d}$ & $42.85^{\mathrm{a}}$ \\
\hline 11 & kanchan & Gaptali of Bogra & 74.0 & 5.5 & 3.0 & 5.6 & 8.2 & 5.7 & $13.62 \mathrm{bc}$ & $40.80^{f}$ \\
\hline 12 & Sonalika & Gaptali of Bogra & 82.1 & 4.5 & 3.5 & 3.5 & 3.9 & 2.5 & $10.97 \mathrm{k}$ & $41.35^{\mathrm{de}}$ \\
\hline 13 & Prodip & Sariakandi of Bogra & 79.0 & 4.5 & 6.0 & 4.0 & 3.5 & 3.0 & $11.80 \mathrm{~g}$ & $40.50^{\mathrm{fg}}$ \\
\hline 14 & Sonalika & Sariakandi of Bogra & 80.3 & 6.0 & 3.0 & 4.0 & 3.2 & 3.5 & $13.61 \mathrm{c}$ & $40.70^{f}$ \\
\hline 15 & Sonalika & Sariakandi of Bogra & 83.0 & 4.0 & 3.5 & 4.3 & 3.0 & 2.2 & $12.30 \mathrm{~d}$ & $40.20^{\text {gh }}$ \\
\hline 16 & BARI gom 25 & Raypur,Manda of Naogan & 85.8 & 3.2 & 2.3 & 3.3 & 2.5 & 2.9 & $10.89 \mathrm{~m}$ & $40.70^{f}$ \\
\hline 17 & BARI gom 26 & Borddapur, Manda of Naogan & 81.0 & 5.0 & 3.5 & 4.5 & 3.3 & 2.7 & 10.911 & $40.70^{f}$ \\
\hline 18 & BARI gom 27 & Durgapur, Manda of Naogan & 84.0 & 3.0 & 3.5 & 2.5 & 4.0 & 3.0 & $11.52 \mathrm{j}$ & $42.80^{\mathrm{a}}$ \\
\hline 19 & BARI gom 28 & Rampur, Manda of Naogan & 86.7 & 2.9 & 3.0 & 2.5 & 2.5 & 2.4 & $10.22 n$ & $40.00^{\mathrm{h}}$ \\
\hline 20 & Satapdi & Raninagar of Naogan & 84.0 & 3.0 & 3.5 & 2.5 & 4.2 & 2.8 & $13.63 \mathrm{~b}$ & $40.70^{f}$ \\
\hline 21 & Sonalika & Raninagar of Naogan & 81.0 & 5.0 & 4.0 & 4.5 & 2.5 & 3.0 & $10.88 \mathrm{~m}$ & $41.50^{\text {cde }}$ \\
\hline \multicolumn{9}{|c|}{ Level of Significance (1\%) } & $* *$ & $* *$ \\
\hline
\end{tabular}

Data represents the mean of three replications. Different grade of wheat seeds (0-5 rating scale of CIMMYT, Gilchist, 1985): $0=$ free from infection, $1=$ only embryo blakish, $2=$ embryo and its adjacent area slightly infected, $3=$ embryo and less than $1 / 4$ of grains are discolored, $4=$ embryo and $1 / 2$ of grains are infected, $5=$ grains are shriveled and almost completely discolored or more than $1 / 2$ of grains discolored.

Dupchanchia of Bogra. Khan et al. (2005) reported in healthy seeds present lowest incidence of fungi and as a resulted highest percentage of germination. Chowdhury (2008) reported that the reduction of germination was found in respect to the severity of black point infection.

Effect of seed treatment with selected plant extracts, $B A U$-Biofungicide and chemical fungicides on seed borne fungi of wheat seeds cv. Kanchan (Blotter Method)

Effect of seed treatment with selected plant extracts (Mehedi, Basok, Marigold and Chirota), BAUBiofungicide and chemical fungicides (Bavistin, Tilt and Provex) on germination and seed borne fungi infection of wheat seeds cv. Kanchan (Blotter Method) are presented in (Table 3). A total number of 6 fungal species belonging to 5 genera were associated with wheat seeds which were Bipolaris sorokiniana (0.0 to $11 \%$ ), Alternaria tenuis (0.0 to $11.5 \%$ ), Fusarium moniliforme (0.0 to $2.5 \%$ ),
Fusarium oxysporum (0.0 to 10.5\%), Curvularia lunata (0.0 to $7.5 \%$ ) and Aspergillus niger (0.0 to $7.5 \%$ ). Percent of germination ranged from $56.0 \%$ to $98.0 \%$ that varied from treatment to treatment in. The highest germination was recorded in case of seed treatment with BAU-Biofungicide and the lowest germination was found in seed treatment with Tilt. Among the treatments BAU-Biofungicide showed superior influence on germination of very susceptible wheat variety of Kanchan over Unterated control in Blotter method as well as Tray method. Upto $15.29 \%$ and $15.47 \%$ higher germination in Blotter and Tray method, respectively over control were achieved by treating seeds with BAU-Biofungicide. This result supported by Naznin (2004) and Yeasmin (2004). Naznin (2004) reported BAU-Biofungicide increase germination 7.92 to $50.80 \%$ over untreated control seed of Sweet gourd, Snake gourd, Cowpea, Cucumber and Okra. Yeasmin (2004) reported that germination of BAU-Biofungicide treated seeds of 
Naznine et al. (2016), Progressive Agriculture 27 (2): 101-109

Table 2. Incidence of fungi obtained through blotter incubation tests

\begin{tabular}{|c|c|c|c|c|c|c|c|c|c|c|c|}
\hline \multirow{2}{*}{$\begin{array}{l}\text { Sl. } \\
\text { No. }\end{array}$} & \multirow[t]{2}{*}{ Variety } & \multirow[t]{2}{*}{ Location of seed colection } & \multirow{2}{*}{$\begin{array}{c}\% \\
\text { Germination }\end{array}$} & \multicolumn{8}{|c|}{$\%$ Seed borne fungi } \\
\hline & & & & $\begin{array}{c}\text { Bipolaris } \\
\text { sorokiniana }\end{array}$ & $\begin{array}{c}\text { Alternaria } \\
\text { tenuis }\end{array}$ & $\begin{array}{c}\text { Fusarium } \\
\text { moniliforme }\end{array}$ & $\begin{array}{c}\text { Fusarium } \\
\text { oxysporum }\end{array}$ & $\begin{array}{c}\text { Curvularia } \\
\text { lunata }\end{array}$ & $\begin{array}{l}\text { Aspergillus } \\
\text { flavus }\end{array}$ & $\begin{array}{c}\text { Aspergillus } \\
\text { niger }\end{array}$ & $\begin{array}{l}\text { Penicillium } \\
\text { spp. }\end{array}$ \\
\hline 1 & Akbar & Dupchanchia of Bogra & 90.0 & 9.5 & 4.5 & 0.0 & 36.5 & 16.5 & 0.0 & 0.0 & 0.0 \\
\hline 2 & Kanchan & Dupchanchia of Bogra & 73.5 & 30.5 & 3.5 & 33.5 & 53.0 & 8.0 & 0.0 & 0.0 & 1.0 \\
\hline 3 & Barkat & Kahaloo of Bogra & 91.0 & 17.5 & 25.0 & 3.0 & 13.0 & 7.0 & 0.0 & 0.0 & 0.0 \\
\hline 4 & Sonalika & Kahaloo of Bogra & 92.0 & 3.5 & 16.5 & 14.5 & 21.5 & 31.5 & 0.0 & 0.0 & 0.0 \\
\hline 5 & Paban & Alta, Nandigram of Bogra & 93.5 & 15.0 & 6.5 & 21.5 & 16.0 & 14.5 & 1.0 & 3.5 & 0.5 \\
\hline 6 & sonalika & Alta, Nandigram of Bogra & 92.5 & 9.5 & 15.0 & 1.0 & 20.5 & 10.0 & 0.0 & 0.0 & 0.0 \\
\hline 7 & Paban & Bijrul, Nandigram of Bogra & 93.0 & 11.0 & 11.5 & 4.0 & 17.0 & 23.5 & 1.0 & 4.0 & 0.5 \\
\hline 8 & Sonalika & Bijrul, Nandigram of Bogra & 96.5 & 12.0 & 16.0 & 2.5 & 2.7 & 6.0 & 0.0 & 0.0 & 0.0 \\
\hline 9 & Prodip & Sonatola of Bogra & 92.5 & 4.5 & 11.5 & 2.5 & 16.5 & 21.5 & 1.0 & 18.5 & 0.0 \\
\hline 10 & Sonalika & Sonatola of Bogra & 87.0 & 12.5 & 9.0 & 7.0 & 8.0 & 24.5 & 2.0 & 4.0 & 1.5 \\
\hline 11 & kanchan & Gaptoli of Bogra & 78.0 & 19.0 & 24.0 & 29 & 42.5 & 18.5 & 0.0 & 0.0 & 0.0 \\
\hline 12 & Sonalika & Gaptoli of Bogra & 96.0 & 0.5 & 7.5 & 2.0 & 12.0 & 7.0 & 0.5 & 2.5 & 0.0 \\
\hline 13 & Prodip & Sariakandi of Bogra & 93.0 & 5.5 & 21.0 & 3.0 & 35.0 & 5.0 & 0.0 & 0.0 & 0.0 \\
\hline 14 & Sonalika & Sariakandi of Bogra & 82.5 & 3.5 & 16.5 & 14.5 & 21.0 & 30.0 & 0.0 & 0.0 & 0.0 \\
\hline 15 & Sonalika & Sariakandi of Bogra & 90.0 & 10.5 & 12.0 & 7.5 & 10.5 & 25.5 & 0.0 & 0.0 & 0.0 \\
\hline 16 & BARI gom 25 & Raypur,Manda of Naogan & 96.0 & 8.0 & 1.0 & 8.5 & 15.0 & 1.5 & 0.5 & 0.0 & 0.0 \\
\hline 17 & BARI gom 26 & Borddapur,Manda of Naogan & 97.0 & 15.5 & 8.0 & 19.5 & 13.0 & 0.0 & 0.0 & 0.5 & 0.0 \\
\hline 18 & BARI gom 27 & Durgapur, Manda of Naogan & 97.0 & 1.0 & 0.5 & 5.5 & 20.5 & 5.5 & 3.5 & 3.0 & 0.0 \\
\hline 19 & BARI gom 28 & Rampur, Manda of Naogan & 98.0 & 13.0 & 4.5 & 20.5 & 14.0 & 4.0 & 5.5 & 0.0 & 0.0 \\
\hline 20 & Satapdi & Raninagar of Naogan & 81.5 & 4.5 & 15.5 & 6.0 & 13.5 & 13.5 & 2.5 & 4.0 & 0.5 \\
\hline 21 & Sonalika & Raninagar of Naogan & 96.0 & 11.0 & 21.0 & 5.5 & 17.5 & 7.0 & 4.9 & 9.5 & 0.0 \\
\hline
\end{tabular}


Table 3. Effect of seed treatment with selected plant extracts, BAU-Biofungicide and chemical fungicides on percent seed borne infection of wheat seeds cv. Kanchan (Blotter Method)

\begin{tabular}{|c|c|c|c|c|c|c|c|c|}
\hline \multirow[b]{2}{*}{$\begin{array}{l}\text { SI. } \\
\text { No. }\end{array}$} & \multirow{2}{*}{$\begin{array}{l}\text { Treatment } \\
\text { (dose) }\end{array}$} & \multirow{2}{*}{$\begin{array}{c}\% \\
\text { Germination }\end{array}$} & \multicolumn{6}{|c|}{$\%$ Seed borne fungi } \\
\hline & & & $\begin{array}{c}\text { Bipolaris } \\
\text { sorokiniana }\end{array}$ & $\begin{array}{c}\text { Alternaria } \\
\text { tenuis }\end{array}$ & $\begin{array}{c}\text { Fusarium } \\
\text { moniliforme }\end{array}$ & $\begin{array}{c}\text { Fusarium } \\
\text { oxysporum }\end{array}$ & $\begin{array}{c}\text { Curvularia } \\
\text { lunata }\end{array}$ & $\begin{array}{c}\text { Aspergillus } \\
\text { niger }\end{array}$ \\
\hline 1. & $\begin{array}{l}\text { Untreated } \\
\text { control }\end{array}$ & 85.0 & 11.0 & 11.5 & 10.2 & 10.5 & 7.5 & 2.5 \\
\hline 2. & $\begin{array}{l}\text { Mehedi leaf } \\
\text { extract }(1: 10)\end{array}$ & 93.5 & 4.5 & 4.0 & 1.5 & 10.0 & 0.5 & 0.5 \\
\hline 3. & $\begin{array}{l}\text { Basok leaf } \\
\text { extract }(1: 10)\end{array}$ & 93.0 & 9.5 & 0.5 & 2.5 & 8.5 & 0.0 & 0.0 \\
\hline 4. & $\begin{array}{l}\text { Chirota plant } \\
\text { extract }(1: 10)\end{array}$ & 93.5 & 8.0 & 1.0 & 2.5 & 9.0 & 2.0 & 0.5 \\
\hline 5. & $\begin{array}{l}\text { Marigold leaf } \\
\text { extract (1:10) }\end{array}$ & 96.0 & 2.0 & 2.5 & 1.5 & 4.5 & 0.0 & 0.0 \\
\hline 6. & $\begin{array}{l}\text { BAU- } \\
\text { Biofungiide } \\
(3.0 \%)\end{array}$ & 98.0 & 0.0 & 0.0 & 0.0 & 0.5 & 0.0 & 0.0 \\
\hline 7. & $\begin{array}{l}\text { Provex } \\
(0.4 \%) \\
\end{array}$ & 96.0 & 0.0 & 2.5 & 0.5 & 0.5 & 0.0 & 0.0 \\
\hline 8. & Tilt $(0.3 \%)$ & 56.0 & 0.0 & 0.0 & 0.0 & 0.0 & 0.0 & 0.0 \\
\hline 9. & $\begin{array}{l}\text { Bavistin } \\
(0.3 \%)\end{array}$ & 97.5 & 0.5 & 5.5 & 0.5 & 1.0 & 1.0 & 1.5 \\
\hline
\end{tabular}

gram, BARI Moog-2 and BARI Lentil-2 was $14 \%$, $20 \%$ and $8 \%$ higher germination over control in tray method. The seed treating chemicals Bavistin, showed good effect in increasing germination of very susceptible wheat variety of Kanchan. This result supported by Bhuiyan et al. (2013) who reported that Bavistin reduced seed-borne infection and increased seed germination over control. But as a seed treating chemical effect of Tilt was not so good, it reduced seed germination in Blotter and Tray method 34.12\% and $50 \%$, respectively. The present finding supported by the reports of Singh (2011) who reported $66.6 \%$ germination was reduction in case of Tilt treated seeds. In the present investigation all the botanicals was significantly reduced seed borne fungal pathogens of wheat, simultaneously increased the germination percentage and growth characters of wheat seedling. However among the 4 extracts, marigold leaf extracts performed better in reducing seed-borne prevalence of all major fungi and increasing germination of very susceptible wheat variety of Kanchan. The present finding supported by the reports of Hanson and Christenan (2005) who reported plant extracts significantly reduced the incidence of seed-borne fungi, increased seed germination.
Effect of seed treatment with selected plant extracts, BAU-Biofungicide and chemical fungicides on \% seed germination, \% non-germinated seed, \% normal seedling, \% abnormal seedling, shoot length, root length and vigor index of wheat seeds cv. Kanchan (Tray method)

Germination of seeds ranged from 42.0 to $97.0 \%$ while the highest germination was recorded in case of seed treatment with BAU-Biofungicide and the lowest in seed treatment with Tilt (Table 4). The number of normal seedling ranged from 28.0 to $96.0 \%$ while the maximum normal seedling was found in seed treatment with BAU-Biofungicide and the minimum in seed treatment with Tilt. The number of abnormal seedling ranged from 1.0 to $14.0 \%$ while the maximum abnormal seedling was found in seed treatment with Tilt and the minimum in seed treatment with BAU-Biofungicide which was followed by seed treatment with Provex and Bavistin. Vigor index ranged from 955.50 to $3186.24 \%$ while the highest vigor index was recorded in seed treatment with BAU-Biofungicide and the lowest in seed treatment with Tilt. It had been found that seed treatment with BAUBiofungicide resulted superior effect over all other treatments in increasing formation of normal 
seedling and vigor index of very susceptible wheat variety of Kanchan (Tray method). Similar results were found by Hossain and Naznin (2005) and Bhuiyan et al. (2006). Hossain and Naznin (2005) conducted an experiment on BAU-Biofungicide in controlling seedling diseases of some summer vegetables to determine the effectiveness of BAUBiofungicide.

Table 4. Effect of seed treatment with selected plant extracts, BAU-Biofungicide and chemical fungicides on seed germination, \%normal seedling, \%abnormal seedling and vigor index of wheat seeds cv. Kanchan (Tray method)

\begin{tabular}{|c|c|c|c|c|c|}
\hline $\begin{array}{l}\text { Sl. } \\
\text { No. }\end{array}$ & Treatment & $\begin{array}{c}\% \% \\
\text { Germination }\end{array}$ & $\begin{array}{c}\text { \% } \\
\text { Normal } \\
\text { seedling }\end{array}$ & $\begin{array}{c}\% \\
\text { Abnormal } \\
\text { seedling }\end{array}$ & $\begin{array}{l}\text { Vigor } \\
\text { index }\end{array}$ \\
\hline 1 & Untreated control & $84^{\mathrm{f}}$ & $72^{f}$ & $12^{\mathrm{b}}$ & $2247.84^{\mathrm{g}}$ \\
\hline 2 & Mehedi leaf extract (1:10) & $91^{\mathrm{e}}$ & $86^{\mathrm{e}}$ & $5.0^{\mathrm{c}}$ & $2491.85^{\mathrm{h}}$ \\
\hline 3 & Basok leaf extract $(1: 10)$ & $93^{\mathrm{d}}$ & $90^{\mathrm{d}}$ & $3.0^{\mathrm{d}}$ & $2794.65^{\mathrm{d}}$ \\
\hline 4 & $\begin{array}{c}\text { Chirota plant extract } \\
\qquad(1: 10)\end{array}$ & $94^{\mathrm{cd}}$ & $89^{\mathrm{d}}$ & $4.0^{\mathrm{cd}}$ & $2575.17^{f}$ \\
\hline 5 & $\begin{array}{c}\text { Marigold leaf extract } \\
(1: 10)\end{array}$ & $95^{\mathrm{bc}}$ & $92^{\mathrm{c}}$ & $3.0^{\mathrm{d}}$ & $2884.20^{\mathrm{b}}$ \\
\hline 6 & BAU-Biofungiide $(3.0 \%)$ & $97^{\mathrm{a}}$ & $96^{\mathrm{a}}$ & $1.0^{\mathrm{e}}$ & $3186.24^{\mathrm{a}}$ \\
\hline 7 & Provex $(0.4 \%)$ & $95^{\mathrm{bc}}$ & $95^{\mathrm{ab}}$ & $1.0^{\mathrm{e}}$ & $2586.98^{\mathrm{e}}$ \\
\hline 8 & Tilt $(0.3 \%)$ & $42^{\mathrm{g}}$ & $28^{\mathrm{g}}$ & $14^{\mathrm{a}}$ & $955.50^{\mathrm{i}}$ \\
\hline 9 & Bavistin $(0.3 \%)$ & $96^{\mathrm{ab}}$ & $94^{\mathrm{b}}$ & $1.0^{\mathrm{e}}$ & $2816.75^{\mathrm{c}}$ \\
\hline & $\begin{array}{l}\text { evel of significance } \\
(1 \%)\end{array}$ & $* *$ & $* *$ & $* *$ & $* *$ \\
\hline
\end{tabular}

The use of BAU-Biofungicide increase vigor index of the vegetables seedlings. Bhuiyan et al. (2006) determined the effectiveness BAU-Biofungicide as fungicide in controlling seedling diseases of winter vegetables and also found that the germination and vigor index increased significantly over the control in tray method. In present investigation, it had been found that vigor index increased $41.75 \%$ over control in tray method. This present finding was supported by the reports of Hossain (2012) and Sultana et al. (2009). Hossain (2012) conducted the experiment with 13 plant extracts, BAU-Biofungicide and checks (fungicides Bavistin + Tilt and untreated control) for controlling black point and leaf blight of wheat variety of kanchan. BAU-Biofungicide resulted $55.6 \%$ higher vigor index over control. Sultana et al. (2009) found that seed treatment with BAU-
Biofungicide significantly increased the vigor index of wheat $24.04 \%$ higher over control.

\section{Conclusion}

Based on present findings it may be concluded that quality of wheat seeds collected from different Upazillas of Bogra (Dupchanchia, Kahaloo, Nandigram, Sonatola, Gaptali, Sariakandi) and Naogaon (Manda, Raninagar) districts were not so good. So seeds of wheat preferably be treated before use. The results of the present investigation BAUBiofungicide showed superior effect over all other treatments. So it may be concluded that BAUBiofungicide can successfully be used for ecofriendly management of leaf blight disease of wheat for obtaining higher yield by avoiding chemicals as 
an important alternative to disease management of wheat.

\section{References}

Ahmed S (1994) Effect of water stress in wheat progress. Bangladesh Journal of Agriculture 5(2): 7-11.

Alberta Agriculture and Food (2007) Agdex 100/221.

Baki AA, Anderson JD (1972). Physiological and biological deterioration of seeds. Seed Biology II Academic press, New York pp. 283-315.

Bdliya BS, Alkali G (2008). Efficacy of some plant extracts in the management of cercospora leaf spot of groundnut in the Sudan savanna of Nigeria. Archives Phytopathol. Plant Protect. pp. $1-12$.

Bhuiyan MAHB, Khokon MAR, Hossain I 2006: BAU-Biofungicidein Controlling Seedling Diseases of Winter Vegetables. Bangladesh J. Plant Pathol. 22(1\&2): 1-5.

Bhuiyan MR, Rashid MM, Khan MA, Hoque M, Nessa B, Rafi MY, Latif MA (2013). Ecofriendly Management of Seed Borne fungi for Sustainable Crop Production. Life Science Journal 4-10.

Chowdhury MMH, Hossain I, Day P, Ahmed M, Mahmud H (2013). Effect of seed sources and seed treatments on disease incidence, severity and seed yield of rice in Bangladesh. Journal Agroforestry Environmental 7 (2): 23-27.

Chowdhury SR (2008). Effect of Different Levels of Seed Infection by Bipolaris sorokiniana on Seedling Vigor, Leaf Blight Development and Quality Seed Production of Wheat. MS. Thesis. Department of Plant Pathology, SAU, Dhaka.

Cohen Y, Wang W, Daniel BHB, Daniel YB (2006).

Extracts of Inula viscose control downy mildew of grapes caused by Plasmopara viticola. Phytopathol. 96(4): 417-424.

Fakir GA (1998). Black point disease of wheat in Bangladesh. $2^{\text {nd }}$ Edition. Seed Pathology Laboratory, Bangladesh Agricultural University, Mymensingh. pp. 81.

Fakir GA, Rahman GMM, Islam MR, Rahman MH, Talukder KA (1987). Black point of wheat-A review. Bangladesh. J. Plant Pathol. 3(1\&2): 111.

Fakir GA, Rahman MH, Rahman GMM (1989). Survey on the prevalence of black point fungi of wheat in Bangladesh. Bangladesh. J. Plant Pathol. 5(1\&2): 19-29.

Gilchist LI (1985). CIMMYT method for screening of wheat for Helminthosporium sativam resistant. In: wheat for tropical environment. A proceeding of the international symposium. Sept. 24-28, 1984. Mexico, D. F. sponsored by The United Nations Development Programme and CIMMYT. Pp. 149-151.

Gomez KA, Gomez AA (1984). Statistical procedure for agricultural research. 2nd Edition. John Willey and Sons., New York. pp. 97-111.

Hanson EW, Christensen JJ (2005). The black point disease of wheat in the United States. Minnesota agricultural Experiment Station Technical Bulletin 206. pp. 30.

Harington JF (1972). Seed storage and longevity. Kozlowski TT Seed Biology, Vol. 3 Academic Press, New York and London. pp. 155-214.

Hasan MM, Islam MR, Hossain I, Shirin K (2014). Biological control of leaf spot of groundnut. Journal of Bioscience and Agriculture Research, Online ISSN 2312-7945, Vol. 01 (02): 66-78.

Hossain I, Hossain MM (2001). Effect of black pointed grains in wheat seed samples on germination, seedling vigour and plant stand. Pakistan J. Phytopathology 13 (1): 1-7 (Pakistan).

Hossain I, Mahamud M, Ashrafuzzaman H (1997). Effects of plant extracs on fungi (Bipolaris sorokiniana and Rhizoctonia solani) and okra mosaic disease. Ecoprint, 4(1): 35-42.

Hossain I, Naznin MHA (2005). BAU Bio-fimgicide in controlling seedling diseases of some summer vegetables. Bangladesh Agricultural University Research System 15-35.

Hossain MH, Hossain I (2012). Effect of seed treatment with different botanicals, Bavistin and BAU Bio-fungicide on germination and seedling vigor of groundnut. Bangladesh Agronomy Journal 16 (1): 87-94.

Hossain MM (2012). Biological control of leaf blight ( Bipolaris sorokiniana) of wheat, $\mathrm{PhD}$ Thesis, 
Department of Plant Pathology, Bangladesh Agricultural University, Mymensingh. pp. 123126

Hossain I (2011). Unique ecofriendly means and new dimension of plant disease control in Bangladesh. Department of Plant Pathology, Bangladesh Agricultural University, Mymensingh, Bangladesh.

ISTA (1996). International Rules for Seed Testing. International Seed-Testing Association, Seed Science and Technology 24: 39-42.

ISTA (2001). International Rules for seed Testing Association 31: 107-115.

Khan AA, Rahman DMM, Mian IH (2005). Health status of Farmers chilli seed of Pabna district. Bangladesh. Journal of Seed Science and Technology 9 (1\&2): 125-128

Khanzada, KA, MA Rajput, GS Shah, AM Lodhi and F Mehboob (2002). Effect of seed dressing fungicides for the control of seed borne mycoflora of wheat. Asian Journal of Plant Sciences 1(4):441-444.

Malaker PK, Mian IH 2002: Effect of black point on seed quality and yield of wheat. Bangladesh $J$. Plant Pathol. 18(1\&2): 65-70.

Naznin H (2004). Biological Control of Seedling Diseases of Some Vegetables, MS Thesis, Department of Plant Pathology, Bangladesh Agricultural University, Mymensingh.
Naznin H, Hossain I (2004). Effect of BAUBiofungicide on Germination and Seedling Vigour of Some Summer Vegetables. Bangladesh Journal Seed Science and Technology 8: 85-90.

Singh S, Kaur L, Sirari A, Singh N (2011). Chemical and biological management of seed borne infection of Botrytis cinerea in chickpea. Department of Plant Breeding and Genetics, Department of Plant Pathology, Punjab Agricultural University, Ludhiana-141004. Pl. Dis. Res. 26 (2): 134-144.

Sobiya S, Shazia S, Arshad J (2005). Fungitoxicity of aqueous extracts of allelopathic plants against seed-borne mycoflora of maize. Mycopath. 3(1\&2): 23-26.

Sultana R, Hossain I, Ahmed S, Mamun MAA (2009). Efficacy of BAU-Biofungicide in controlling leaf spot of Wheat (Triticum aestivitm). Eco-friendly Agrilculture Journal 22: 392-395.

Thrimurty VS (1986). Studies on chemical control of sheath rot of rice. Pesticides 9: 20-21.

USDA (United States Department of Agriculture) 2015: World Wheat Production 2015/2016, June 2015.

Yeasmin MR (2004). Integrated Management of Seedling Diseases of Blackgram, Mungbean and Lentil, MS Thesis, Department of Plant Pathology, Bangladesh Agricultural University, Mymensingh. 